\title{
Family meals: a thing of the past
}

\author{
John A Davis
}

To eat together has been a way of symbolising and cementing accord since the beginning of time: indeed it is practised by the king of beasts and many of his subjects, and the Last Supper is only one if the supreme instance of its significance. It is how we greet and come to terms with strangers; it is how societies celebrate when they meet; and of course it is a daily ritual in most families, which it holds together and distinguishes as a group sharing bed and board.

At a time when, rightly or wrongly, our Jeremiahs deplore the loosening of those family ties which are thought to hold together the very fabric of society, it is therefore worrying that in just those elements that are becoming alienated from the rest of the nation there is evidence that breaking bread together is no longer the focal point of family life; a snatched breakfast - if any - being followed by lunch at school or work, with the evening meal a matter of individually finding what is available and gobbling it up in front of the telly or while listening to pop music in one's room or whatever personal space can be appropriated or perhaps hunger is assuaged at a fish and chip shop or the ubiquitous McDonalds. It is said that in some households even the basic requisites of a semiformal meal tables and chairs - are lacking, let alone the accoutrements of civilised eating such as the knives, forks, glasses, dishes, and table napkins such as used to grace the tables even of the poor, or the table manners that went with them. And what has happened to that centrepiece of family life, the Sunday lunch, once prepared with such care and attention to detail and eaten with such relish and solemnity by the Pumblechooks of this world - or even Christmas dinner? These occasions were not of course always enjoyed by children, who too often had to watch in silence while their elders and betters got the best of what was going before falling into postprandial slumber, often to the strains of Wagner on the wireless, to wake with a headache in time for evening service; but as a ceremony they probably served a purpose, even if not preceded or followed by a grace; reminding all those partaking of the sacramental nature of what would otherwise be something akin to pigs wallowing together at a trough. For paediatricians, concerned more with the nutrition of the growing body than the socialising of the unlicked soul, family meal times are important in providing an opportunity for the materfamilias to know what her children are eating, to ensure fair shares, to instil the rudiments of sensible eating and civilised manners, and to see to it that at least sometimes their husbands and children share an important element in their life as a family. How many mothers these days know what their children eat, and if they do, whether it provides a good, indifferent, or inadequate dietary intake? How many fathers, after consuming the lion's share of what is going, bother with their children as long as the children don't bother them? And in how many households are grandparents the most honoured guests at table as they would be in many societies more civilised if less 'developed' than our own?

But perhaps salvation is nearer at hand than we may think. Few British families these days have no experience of the way of life of our European brothers and sisters, nor have failed to notice and perhaps envy those family parties - whether for luncheon or dinner - at which as many as 20 persons of all ages sit down together in a restaurant for what looks a jolly party enjoyed by all from infant at the breast to toothless great grandparent, from fecund mother to maiden aunt, from jolly uncle to stern patriarch.

This is surely the way ahead: the equivalent of Henri Quatre's chicken in the pot for everyone: no chores or anxiety for the working mother, no best behaviour for the children. It should be possible for every British extended family to eat en famille with their peers at least once a week; and the quality of restaurant meals is rising as rapidly as their cost is falling. $A$ bas the special gastronomic relationship with the country of fast food that looks more tempting than it tastes or nourishes; vive la cuisine continentale and its bonhomie. What a slogan for Mr Blair's new look Labour party - a nation in which all classes can eat out together cheaply, well, and in a civilised way for the nourishment of soma and psyche. Take care of that and the vitamins will largely take care of themselves.

PS: What about the British Paediatric Association dining en masse at the Royal College of Physicians?

Bibliograph

Murcott A, ed. The sociology of food and eating; essays on the sociological significance of food. USA: Gower, 1983. 